\title{
Does ultrasound agree with parent's perception of joint disease in juvenile idiopathic arthritis?
}

\author{
Carlo Biancardi ${ }^{*}$, Irene Borzani ${ }^{2}$, Sofia Torreggiani ${ }^{1}$, Antonella Petaccia ${ }^{1}$, Angelo Ravelli ${ }^{3}$, Fabrizia Corona ${ }^{1}$, \\ Giovanni Filocamo ${ }^{1}$
}

From 21st European Pediatric Rheumatology (PReS) Congress

Belgrade, Serbia. 17-21 September 2014

\section{Introduction}

Ultrasound (US) is a powerful tool for the assessment of joint disease in children with juvenile idiopathic arthritis (JIA) and has been shown to be more accurate than clinical examination in detecting synovitis. Parent's proxy-report of joint involvement is potentially usefulto obtain information on parent's perception of the burden of child's arthritis and may serve as surrogate for physician's articular examination. However, it is unclear whether parents are reliable reporters of their children's disease.

\section{Objectives}

To evaluate the level of agreement between parents' proxy-report of joint involvement and US assessment of joint synovitis in children with JIA.

\section{Methods}

Before the study visit, parents of children with JIA were asked to complete the Juvenile Arthritis Multidimensional Assessment Report (JAMAR), which includes a standardized assessment of the presence of swelling or pain in 9 joints or joint groups, and several other parentcentered JIA outcome measures. At study visit, a pediatric rheumatologist, who was unaware of parent's reports, performed a formal joint assessment and scored the presence or absence of swelling and tenderness/pain on motion in the same joints assessed by the parent. After the visit, a pediatric radiologist with more then 5 years of experience in US assessment in JIA evaluated independentlythe presence of synovial hypertrophy/effusion (gray scale US - GSUS) and Power Doppler (PD) inmetacarpophalangeal and interphalangeal joints, knees and ankles, and quantified each US featureon a 0-3 semi-quantitative scale. Agreement between parent, rheumatologist, and ultrasonographerin joint assessment was computed by means of Cohen's kappa and was categorized as follows: $<0.40=$ poor; $0.41-0.60=$ moderate; $0.61-0.80=$ substantial; $>0.80$ excellent.

\section{Results}

The JAMAR was completed by parents of 10 unselected patients, 8 with persistent oligoarthritis, 1 with extended oligoarthritis and 1 with rheumatoid factor-negative

\section{Table 1}

\begin{tabular}{|c|c|c|c|c|c|c|}
\hline Joint & $\begin{array}{l}\text { GSUS vS } \\
\text { parent }\end{array}$ & $\begin{array}{l}\text { PDUS vs } \\
\text { parent }\end{array}$ & $\begin{array}{l}\text { GSUS vs physician } \\
\text { swelling }\end{array}$ & $\begin{array}{c}\text { PDUS vs physician } \\
\text { swelling }\end{array}$ & $\begin{array}{c}\text { GSUS vs physician pain/ } \\
\text { LOM }\end{array}$ & $\begin{array}{c}\text { PDUS vs physician pain/ } \\
\text { LOM }\end{array}$ \\
\hline $\begin{array}{l}\text { Hand } \\
\text { joints }\end{array}$ & 0.62 & $-£$ & 0.62 & $-£$ & 0.62 & $-£$ \\
\hline Knee & 0.70 & 0.67 & 0.62 & 0.77 & 0.62 & 0.77 \\
\hline Ankle & 0.47 & 0.62 & 0.57 & 0.69 & 0.47 & 0.62 \\
\hline
\end{tabular}

$£$ Not assessed because PDUS score was $=0$.

\footnotetext{
'UOS Reumatologia Pediatria, Dipartimento della Donna, del Bambino e del Neonato, Milano, Italy

Full list of author information is available at the end of the article
} 
polyarthritis, aged 22 months to 8 years. The median (range) of JADAS71 in the 10 patients was 10 (0-19).

Table 1 shows the $\mathrm{k}$ values for agreement in joint assessment between parents, physician and ultrasonographer evaluation.

\section{Conclusion}

Our results show moderate-to-substantial agreement between parents' proxy report of joint disease and US assessment. Concordance with US was similar for parents and physicians. This finding suggests that parents are reliable reporters of the extension and severity of their children's arthritis. Overall, concordance was greater for PDUS than for GSUS and was lower for the ankle than for the other joints.

\section{Disclosure of interest}

None declared.

\section{Authors' details}

'UOS Reumatologia Pediatria, Dipartimento della Donna, del Bambino e del Neonato, Milano, Italy. ${ }^{2}$ UO Radiologia Pediatrica, Dipartimento della Donna, del Bambino e del Neonato, Fondazione IRCCS Cà Granda Ospedale Maggiore Policlinico, Milano, Italy. ${ }^{3}$ Pediatria II, Istituto Giannina Gaslini and Università di Genova, Genoa, Italy.

Published: 17 September 2014

Cite this article as: Biancardi et al:: Does ultrasound agree with parent's perception of joint disease in juvenile idiopathic arthritis? Pediatric

Rheumatology 2014 12(Suppl 1):P172.

Submit your next manuscript to BioMed Central and take full advantage of:

- Convenient online submission

- Thorough peer review

- No space constraints or color figure charges

- Immediate publication on acceptance

- Inclusion in PubMed, CAS, Scopus and Google Scholar

- Research which is freely available for redistribution

Submit your manuscript at www.biomedcentral.com/submit 